Historic, archived document

Do not assume content reflects current scientific knowledge, policies, or practices. 



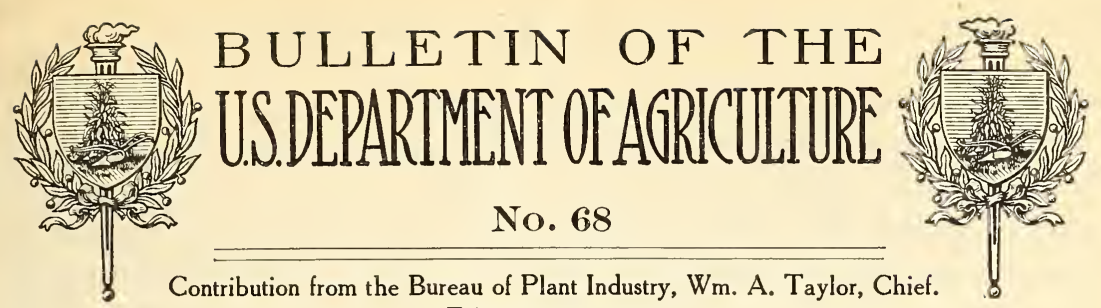

February 25, 1914.

\title{
PASTURE AND GRAIN CROPS FOR HOGS IN THE PACIFIC NORTHWEST.
}

\author{
By Byron Hunter, Agriculturist, Office of Farm Managemerit. ${ }^{1}$
}

\section{INTRODUCTION.}

This bulletin deals specifically with crops and systems of cropping that may be used in economical pork production in the Pacific Northwest. Scattered here and there throughout the Northwest are men who are successfully producing pork. They have been visited, and their methods, crops, and feeding systems have been studied. This bulletin makes the practices of these successful men available to all.

Owing to the rapid growth in population of this section during the last decade, the demand for pork has increased faster than the supply, and there is littlo reason why hog raising should not become a more important industry in the Pacific Northwest. Although there have been some outbreaks of hog cholera, the Northwest has been remarkably free from this disease. The larger cities have wellequipped packing houses, and modern union stockyards are in operation at Portland, Oreg. During recent years a large percentage of the hngs slaughtered in the cities of Portland, Tacoma, Seattle, and Spokane have been shipped from east of the Rocky Mountains. In addition to this, enormous quantities of eastern bacon and lard are annually consumed by the Pacific Coast States.

\section{MANAGEMENT OF PASTURES.}

Since economical pork production depends largely upon the consumption of a great deal of cheaply grown feed, the pasture should be so managed that the forage produced will be clean, tender, and palatable. In practice, hog pastures are generally managed in one of three ways: (1) Continuous close grazing, (2) alternate pasturing of equal areas, and (3) pasturing the meadow.

Nore.-This publication is intended to encourage hog raising in the Pacific Northwest; it is especially adapted to Washington, Oregon, and Idaho.

$1 \mathrm{Mr}$. Hunter is now State leader in charge of Farm-Management Field Studies and Demonstrations in the State of Washington, and is employed cooperatively by the United States Department of Agriculture and the State College of Washington.

$$
\text { 23557ำBull. } 68-14-1
$$




\section{CONTINUOUS CLOSE GRAZING.}

The method in most common use is to turn in all the hogs the pasture will support, leaving them in the field during the entire season. Usually the pasture is kept closely grazed. Too often it is overgrazed, the plants being cropped so closely that the stand is soon ruined. The pasture then becomes little better than a dry lot, and the hogs make unsatisfactory gains. When the feed in the pasture becomes scarce, either the number of hogs per acre should be reduced or other forage provided.

\section{ALTERNATE PASTURING OF EQUAL AREAS.}

One of the most satisfactory ways of managing a pasture is to divide it into two or more fields of equal area. These fields are then used alternately, the hogs remaining in each about a week or 10 days. In the case of clover and alfalfa the growth is allowed to become 3 to 4 inches high before the hogs are turned in to eat it off quickly. When the pasture consists of such crops as rape, kale, and vetch, which will not stand close grazing, the growth is permitted to reach a height of 8 or 10 inehes before the hogs are turned in.

Changing the hogs from field to field gives the pasture a period of rest, during which the plants recuperate and grow rapidly. When the stock is returned to the field the forage is clean, tender, and palatable and large quantities are consumed. Owing to the rapid growth made while at rest, a pasture that is subdivided and the areas grazed alternately is capable of carrying a much larger number of hogs per acre, other conditions being equal, than one that is continuously pastured.

Hogs usually graze a pasture somewhat unevenly, some areas being eaten off much more closely than others. To keep down the weeds and make the growth come on evenly, the pasture is clipped with a mower immediately after the hogs are removed. Hogs are inclined to root when the surface of the ground is wet or damp. For this reason the pasture, if under irrigation, is irrigated just after the hogs are changed from one pasture lot to the next. This gives the surface of the ground time to dry before the forage is large enough to be grazed.

\section{Pasturing THE MEADOW.}

Many successful hog raisers prefer to use such crops as clover and alfalfa for both pasture and hay at the same time. The number of hogs turned into the field is so limited that the usual crops of hay are made. The chief advantages of this method are (1) the presence of an abundance of feed, (2) the meadow is not grazed closely enough for the stand to be injured, (3) it is not necessary to subdivide the pasture into smaller areas for alternate pasturing, and (4) the changing of the hogs from one inclosure to another is obviated. 
When the number of animals pastured is so limited that the usual hay crops are made, the growth becomes so coarse and woody that they do not consume as much forage as is desirable for economical gains, as the hogs relish the young shoots best. When the forage becomes too large to furnish desirable feed, an area near the watering place is clipped with a mower. This should be large enough to furnish the desired amount of pasture. In a few days the clipped area produces a vigorous growth of new shoots, upon which the hogs feed without materially disturbing the rest of the meadow. If the area first mowed is not sufficient to furnish the required feed, more of the meadow is clipped, as necessity may demand. To prevent the

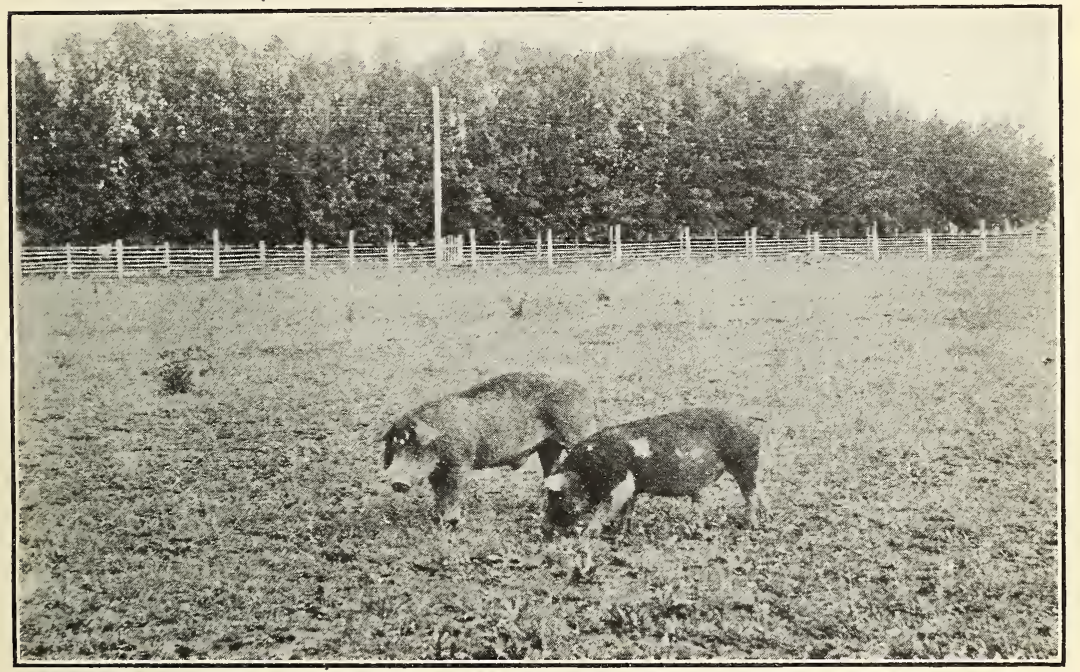

FIG. 1.-Hogs on alfalfa pasture without other feed. Note their thin condition and ungainly shape, especially the older hog on the left.

stand of these clipped areas from becoming injured by overgrazing, different portions of the meadow are used in this way from year to year.

\section{GRAIN RATION WHILE HOGS ARE ON PASTURE.}

While the cost of producing pork may be reduced materially by the use of such roughage as alfalfa hay, roots, or green-pasture forage, it is desirable to feed grain or other concentrated feed in addition. Mature, dry brood sows are sometimes maintained in an apparently satisfactory condition on good pasture alone. Young growing hogs, on the other hand, usually become ungainly in shape, big bellied, and thin in flesh or stunted when compelled to subsist on pasture alone. Figure 1 illustrates the condition of hogs run on pasture without other feed. 
Hog growers differ quite widely regarding the quantity of grain that should be fed while on pasture. Some feed a full grain ration, i. e., all the grain the hog will consume. Others feed a medium ration, one that is equal to about 2 to 3 per cent of the live weight of the hog. Still others prefer a light grain ration, one that is equal to only about 1 per cent of the live weight of the hog: Occasionally men are found who run young shotes on pasture without other feed. This is a mistake, for it almost invariably results in a stunted hog. No fixed and fast rule can be laid down, for the supplemental grain ration which should be fed in conjunction with green pasture depends upon a number of factors, the more important of which are (1) the age at which the hogs are to be marketed, (2) the price of grain, and (3) the plentifulness and quality of the pasture.

\section{RATIONS FOR HOGS OF VARIOUS CONDITIONS AND MARKET AGES.}

If hogs are to be marketed when 7 to 9 months old, it is necessary to feed them about all the grain they will consume, in addition to the pasture, in order to make them reach the weight demanded by the market, 170 to 225 pounds. Hogs that are marketed when 10 to 12 months old are usually maintained on pasture alone during the grazing season. If fed at all, the grain ration is very light. This results in a slow daily gain, but a greater percentage of the growth is made from the cheaply grown forage. The added cost of maintaining a hog until 10 to 12 months old, however, usually more than equals the saving of the grain ration.

Mature breeding stock that is not expected to make any gain in weight requires but little, if any, additional feed when on good pasture. Hogs that are thin in flesh and nearl grown may be expected to make small daily gains without other feed when on the best of pasture. Pigs and small shotes usually become stunted when on pasture unless given a liberal quantity of additional feed. Toung hogs should be so fed that they grow rapidly instead of becoming stunted. During the fattening period, hogs on pasture should be fed all the grain they will eat up clean three times a day.

\section{THE PRICE OF GRAIN.}

Owing to the fluctuation in the price of hogs and of grain, the supplemental grain ration is sometimes expensive. Under such circumstances there is great temptation to place the hogs upon an exclusive pasture ration. This seldom pays, for it usually takes approximately as much concentrated feed in the end, and much more time, to fit for market hogs which have been on an exclusive pasture diet as is required for hogs fed liberally while on pasture. Under extreme circumstances mature breeding stock or hogs which are nearly grown may be carried on good pasture until cheaper concentrated feed can be obtained. 


\section{QUALTTY AND ABUNDANCE OF PASTURE.}

The composition of pasture forage is quite variable. Alfalfa, clover, vetch, peas, etc., furnish feed that is much richer in protein than most other crops. Generally, therefore, hogs which are feeding upon leguminous pasture require slightly less concentrated feed than when grazing upon nonleguminous pasture, such as timothy, orchard grass, bluegrass, or the cereals.

It frequently happens that a farmer has more hogs than his pasture is capable of supporting. When such is the case the pasture will go much farther if a full grain ration is fed. The more grain a hog consumes the less he will feed upon the pasture.

In general, pigs and shotes should be kept in a thrifty, growing condition at all times. It never pays to allow them to cease growing

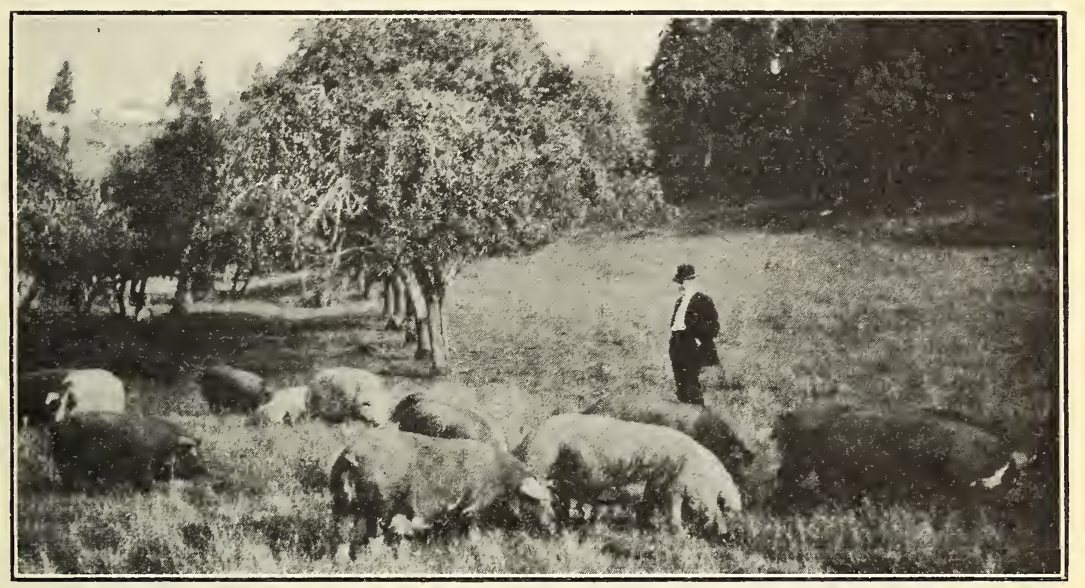

FIG. 2.-A herd of brood sows on pasture. They were fed enough grain to keep them in good condition.

and become stunted. Brood sows, likewise, must be kept in good flesh (not fat) if large litters of strong, healthy pigs are to be expected. Figure 2 shows a herd of well-kept brood sows on pasture.

In gathering the material for this bulletin it was quite generally observed, on the one hand, that the men who are enthusiastic pork producers feed a liberal supplemental grain ration to young, growing hogs when on pasture. On the other hand, those who think there is little profit in raising hogs run them very largely on pasture without other feed during the grazing season.

\section{HOGGING OFF CROPS.}

Turning hogs into a standing field of mature or nearly mature wheat, barley, peas, or corn and allowing them to feed at will until the crop is consumed is called "hogging off" or "hogging down" the 
crop. To some this may appear to be a wasteful practice. Under good management, howerer, it is a rery satisfactory and economical method of utilizing limited areas of these crops.

\section{ADVANTAGES IN HOGGING OFF CROPS.}

Some of the adrantages in hogging off crops are (1) the cost of harresting and marketing the crop is sared, (2) the labor of caring for hogs is greatly reduced, (3) the regetable matter in the soil is increased, (4) the droppings of the animals are distributed quite erenly, and (5) the hogs are giren exercise. It costs from 15 to 25 cents per bushel to harrest and market wheat in the greater part of the wheat belt of the Pacific Northwest, the cost varying with the yield, the method of harresting and thrashing, and the distance the wheat is hauled to market. In some of the more arid wheat-growing districts of both Oregon and Washington the vield of wheat is frequently as low as 6 to 8 bushels per acre. The cost of harvesting and marketing such crops runs from 35 to 40 cents per bushel. The cost of harresting and marketing barley is approximately the same as that of wheat. When the hogs are so managed that the crop is thoroughly cleaned up, hogging off the crop practically sares the cost of harresting and marketing. In the case of light-yielding crops this saving is considerable.

Most of the crops that are suitable for hogging off are utilized during the busiest season of the year, i. e., at a time when it is very desirable that the hozs require as little attention as possible. If turned into a mature field of wheat, peas, or corn and provided with water, shade, and salt, the hogs require rery little other attention.

Most of the arable lands of the Pacific. Northwest would be materially benefited br the addition of more organic matter. Then the crop is hogged off, the straw, pea vines, or cornstalks, as the case may be, are left on the ground. By cutting this material thoroughly in the fall of the year with a sharp disk harrow and plowing it under, the soil is enriched in regetable matter. This, in turn, greatly reduces the tendency of the soil to wash. The washing of soil due to the burning of straw and consequent lack of humus is well shown in figure 3.

In hogging off the crop, the droppings of the animals are scattered quite evenly orer the field.

\section{USUAL GRAIN CROPS HOGGED OFF.}

The Pacific Northwest is peculiarly adapted to the hogging off of crops. The wet season occurs during the winter months and the dry season during the summer. This gives a long period in which crops may be used in this way. The principal crops that are suitable for hogging down are wheat, field peas, corn, and barley. 
Wheat.- Wheat is generally used from the time the first spots in the field are nearly ripe, about the stiff-dough stage, until the stubble field is open or until field peas or some other crops are ready for use. It will be seen, then, that the season for using wheat is from four to six weeks. If used during a longer period, there may be considerable loss from shattering, and the autumn rains in some localities may also damage the crop.

A soft variety of wheat with a smooth club type of head is best suited for hogging down. The club head does not shatter so readily as most other types. The true hard and bearded varieties, such as Turkey, are not suitable. The kernels become so hard and the beards are so severe on the hogs' mouths that they do not eat enough to make economical gains.

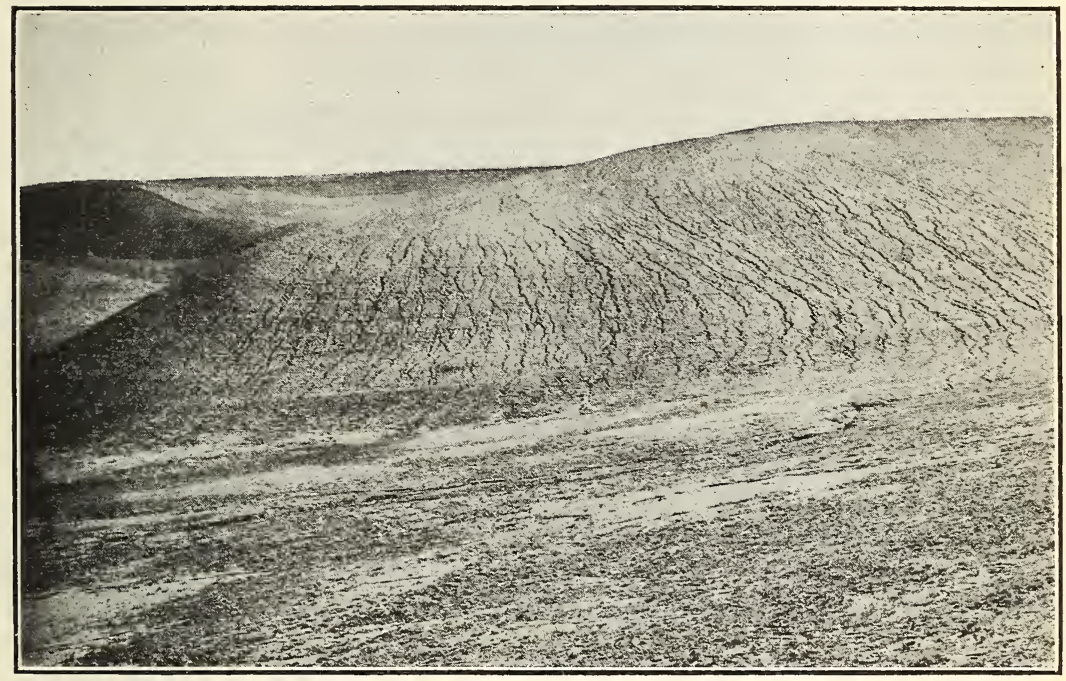

FIG. 3.-Soil washing near Dayton, Wash., in the spring of 1910. This land was summer-fallowed during the season of 1909 and planted to winter wheat.

On the farm of W. H. Steen, Umatilla County, Oreg., 90 hogs pastured from July 17 to August 24 on 11 acres of ripe standing wheat, estimated to yield 15 bushels per acre, made an average gain in weight of 160 pounds per acre, worth $\$ 14.40$. In another instance M. E. Schreck, of Whitman County, Wash., pastured 109 head of hogs on $7 \frac{3}{16}$ acres of standing wheat and 1 acre of pasture from July 30 to August 17. The hogs made a gain of 212 pounds per acre and gave a net value per acre of $\$ 15.73$. The net returns from 44 acres of wheat alongside, yielding $19 \frac{3}{4}$ bushels per acre, were only $\$ 8.04$ per acre.

Field peas.-The field pea is one of the most satisfactory crops to harvest with hogs. The quality of feed furnished is of the very best, hogs are very fond of the mature peas, and under good management 
the crop is gathered with but very little waste. Most rarieties of peas are comparatively large and difficult to cover. What is shattered usually lies on the surface of the ground until picked up later.

The hogs are turned into the field about the time the last peas are nearly mature. In most districts they may be used until about October 1, or until there is danger of the crop being damaged by wet weather. A protracted autumn rain falling upon a heavy crop that the hogs have not cleaned up may cause the peas to sprout. To prevent this the rines are sometimes burned as soon after the rain as they are dry enough. Burning the vines leaves the peas lying upon the surface of the ground. It is not necessary to burn the vines, however, if a movable fence is used and the hogs are made to clean up the crop in small areas that will last from two to three weeks each. Since ripe, mature peas are rich in protein, green succulent feed in addition to the peas will help to balance the ration.

Corn.- Where corn is successfully grown it is an excellent crop to hog down. Carefully conducted tests at the Minnesota experiment station show that hogs waste no more corn in the field than when fed in lots, and that they gather it as clean as most men do in husking. ${ }^{1}$ Farm experience also bears out this conclusion. Corn is advantageously used from the time the ears are well glazed until the weather becomes unfavorable and the ground muddy. In some districts of the Northwest, where the rainfall is scant, corn can be hogged off far into the winter. There is slightly less waste if a movable fence is used and the hogs are not turned into more corn than they can consume in 15 or 20 days. Especially is this true when the ground becomes wet and muddy.

Barley.-As a crop to hog off, barley is used during the summer, autumn, and winter. Because the beards, when dry and hard, are so severe on the mouth of the hog; the common beardless barley is generally used during the summer and early autumn. The bearded varieties usually outyield the beardless considerably, and for this reason the former are generally preferred for late autumn and winter use. There are some, however, who prefer the beardless varieties for all seasons.

If sown very early in the spring, beardless barley generally ripens about ten days or two weeks earlier than winter wheat. This makes it one of the first crops available for hogging off in the early summer. The hogs are turned into the field when the first patches are ripening, or when the kernels are in the stiff-dough stage.

Hogs do only fairly well on mature bearded barley when the beards are dry and stiff. After the autumn rains have softened the beards and kernels, however, they take to it readily. For late autumn and

1 Gaumnitz, D. A., Wilson, A. D., and Bassett, L. B. Pork production. Minnesota Agricultural Experiment Station, Bulletin 104, p. 63-119, 9 fig., 1907. 
winter use the bearded varieties are allowed to stand in the field until the fall rains have set in well. This usually gives plenty of time after harvest for the hogs to glean the stubble field. Blue barley, a bearded variety, is generally sown for late fall and winter use. When allowed to stand in the field it does not shatter and sprout nearly so easily as wheat or the so-called winter varieties of barley.

On a farm in Umatilla County, Oreg., during November, 1910, 80 hogs were pastured 18 days and 98 hogs 10 days on 11.4 acres of barley on a steep hillside. The gain in weight averaged 230 pounds per acre, having a value of $\$ 18.35$ per acre. The estimated yield of

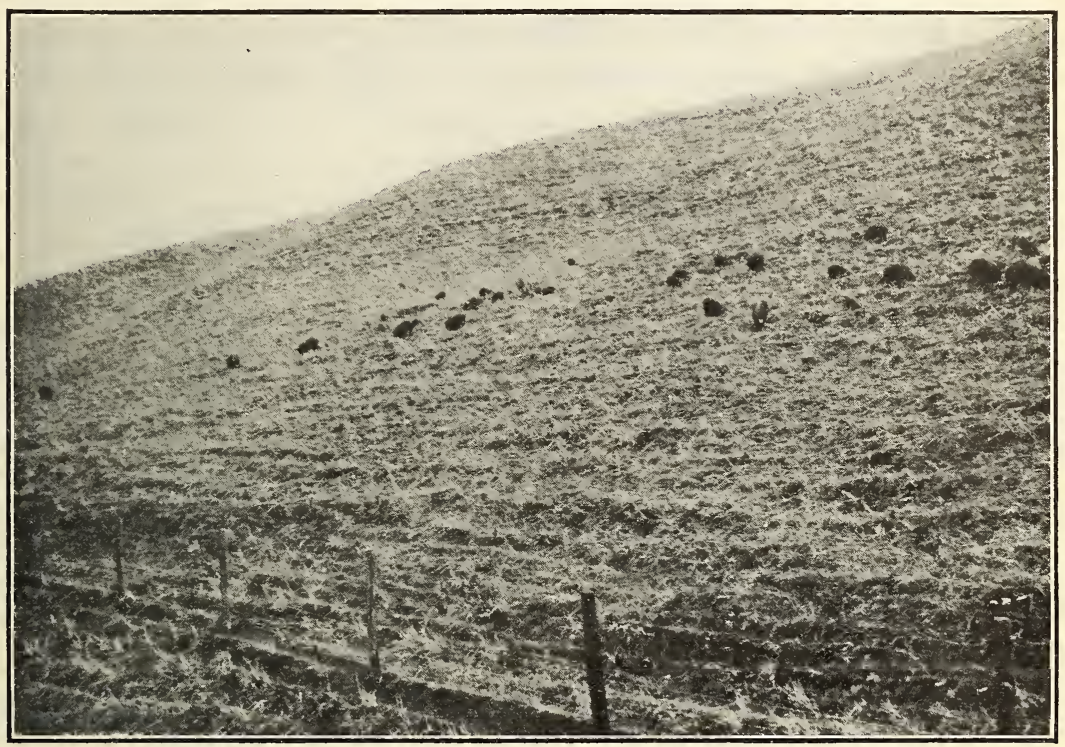

FIG. 4.-A hillside on the farm of W. H. Steen, Umatilla County, Oreg., too steep for the use of a binder, but satisfactorily harvested by hogs. The shotes in the picture are gleaning the barley after the fattening hogs have taken the greater part of the feed.

barley was 21 bushels per acre. Figure 4 shows the hillside with shotes gleaning the barley after the fattening hogs have taken off practically all the feed.

DETERMINING THE AREA TO BE HOGGED OFF.

In order to reduce the waste to a minimum, the area of each crop hogged off must be thoroughly cleaned up. Owing to the variation in crop yields and the quantity of grain that hogs of different sizes will consume, it is not always easy to determine the acreage of each crop to be used in this way. Suppose a portion of the main winterwheat crop is to be fenced and hogged off from the time the grain is just past the stiff-dough stage, say July 10, until the stubble field is open, August 15. What area of the winter wheat shall be set aside $23557^{\circ}-$ Bull. $68-14-2$ 
to be used in this way? This may be determined in two ways, as follows:

(1) When the first spots in the field are nearly ripe or when the kernels have just passed the stiff-dough stage, measure and fence a small trial area, enough to last the herd of hogs for only a ferw days. From July 10 to August 15 is 36 days. If a trial area of one acre lasts the herd 6 days, as many acres of wheat must be reserved as the number of times 6 is contained in 36 , or 6 acres.

(2) By the second method, the yield of the crop per acre and the quantity of feed that the herd of hogs will consume per day are estimated. Suppose that the yield of wheat is 30 bushels, or 1,800 pounds, per acre and the herd of hogs will consume 400 pounds of wheat per day. If 400 pounds of wheat are consumed in one day, an acre. or 1,800 pounds, will last 4.5 days. If one acre lasts 4.5 days, 8 acres will be required to last 36 days, i. e., from July 10 to August 15.

The quantity of wheat that the herd of hogs will consume per day can be determined quite accurately by weighing their feed for a few days just before they are turned into the field. In the case of growing hogs, they will consume a little more each day as they grow older.

THE AREA OF GRAIN TO HOG OFF AT ONE TIME.

Crops are hogged off in two ways: (1) By subdividing the field with a movable fence into small areas that will last the hogs from 10 to 20 days and (2) by turning the hogs into the entire field in the beginning.

No data are at hand showing which of these methods is more economical. While both are used in the Pacific Northwest, the latter is the one generally practiced. Where crops are used in this way during the late fall and winter in the more humid portions of the wheat belt and west of the Cascade Mountains, where the autumn rains are frequently heavy, the area should probably be limited so that it will be cleaned up in 15 or 20 days. In the arid and semiarid districts or when used during the dry season in the more humid localities, there is probably no good reason why the area hogged off should not be all that the hogs will clean up nicely during the season. Much larger areas doubtless can be hogged off on sandy or gravelly soils than on clay soils that become sticky when wet.

\section{CROPS SUITABLE FOR PASTURE AND HOGGING OFF.}

The three Pacific Northwestern States to which this bulletin is primarily applicable may be divided into three distinct agricultural districts: (1) Western Oregon and western Washington-that portion of these two States lying west of the Cascade Mountains, (2) the wheat belt, and (3) the irrigated valleys. Because of their great variation in topography, elevation, rainfall, soil, temperature, etc., these three districts present a wide range of agricultural possibilities. For this reason the crops that may be used in economical hog production in each area are discussed separately. 
CROPS FOR WESTERN OREGON AND WESTERN WASHINGTON.

The moist, mild climate of this district makes it possible to provide an abundance of cheaply grown forage for hogs throughout the entire year. The number of crops which may be used for this purpose is very great. The growing of most of them is discussed in detail in Farmers' Bulletin 271 of this department, "Forage Crop Practises in Western Oregon and Western Washington," to which the reader is referred. Only such points of information as can not be easily found elsewhere are presented here.

$$
\text { USE OF VARIOUS PASTURE CROPS. }
$$

Table I shows suitable pasture crops in western Oregon and western Washington, with the dates of planting and use.

TABLE I.-Pasture crops for western Oregon and western Washington.

\begin{tabular}{|c|c|c|c|}
\hline Crops. & When planted. & Approximate dates when used. & $\begin{array}{l}\text { Number } \\
\text { of hogs } \\
\text { an acre } \\
\text { will } \\
\text { pasture. } 1\end{array}$ \\
\hline Clover.. & $\Lambda$ previous year. & April 1 to Norember $1 .$. & 8 to 16 \\
\hline Alfalfa........ & ..... do ............. & ..... do ................ & 8 to 16 \\
\hline Rape in rows... & April 1,15 , and $30 .$. & June 1 to November $1 .$. & 8 to 14 \\
\hline Rape and oats... & April 25 to May $15 . .$. & June 25 to November 1 . & 6 to 15 \\
\hline Rape and clover....... & May 15 to June $1 . \ldots \ldots \ldots \ldots$ & July 1 to November $1 \ldots$ & 6 to 15 \\
\hline Rape................................ & $\begin{array}{l}\text { July (in corn at last cultiva- } \\
\text { tion). }\end{array}$ & October 1 to April $1 . . .$. & 5 to 8 \\
\hline $\begin{array}{l}\text { Vetch and wheat, retch and } \\
\text { oats, or vetch alone. }\end{array}$ & 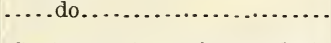 & ..... do.. & 5 to 8 \\
\hline $\begin{array}{l}\text { Vetch and wheat or vetch and } \\
\text { oats. }\end{array}$ & September (on spring stubble). & November 1 to April $1 . . . . .$. & 5 to 8 \\
\hline $\begin{array}{l}\text { English rye-grass } \ldots \ldots \ldots \ldots \\
\text { Winter wheat. } \ldots \ldots \ldots\end{array}$ & Early spring or early fall...... & November 1 to July $1 \ldots \ldots \ldots$ & 5 to 14 \\
\hline $\begin{array}{l}\text { Winter wheat } \ldots \ldots \\
\text { Vetch } . . .1 .\end{array}$ & $\begin{array}{l}\text { September } 1 \text { to October } 15 . . . \\
\text { September..................... }\end{array}$ & $\begin{array}{l}\text { February, March, and April... } \\
\text { March to July } 1 . . . .\end{array}$ & $\begin{array}{l}6 \text { to } 12 \\
8 \text { to } 16\end{array}$ \\
\hline
\end{tabular}

1 The number of hogs that can be pastured per acre depends upon (1) the productiveness of the soil, (2) the variation of the season, (3) the management of the pasture, (4) the size of the hogs, and (5) the kind and quantity of other feed the hogs receive in addition to the pasture.

From a study of Table I it will be seen that pasture may be provided for swine in western Oregon and western Washington throughout the entire year. It is not intended that all of these crops shall be used on any one farm. The purpose of the table is to assist the farmer in the selection of pasture crops which may meet the needs and conditions of his farm.

If intended for late fall, winter, and early spring use, a pasture should not be grazed during the autumn, in order that a large amount of forage may accumulate. This is necessary with almost all winter forage crops, for growth practically ceases when winter begins. The forage that is allowed to accumulate during the autumn is grazed during the winter.

It must be understood also that there are times during the winter when most soils west of the Cascade Mountains become so wet that the tramping of the hogs does a great deal of injury by puddling the soil. For this reason it is generally considered best to remove the hogs from the pasture when a heavy rain faills. This is not always 
necessary, however, as, for example, on sandy soils and pastures with a close grass sod.

Clover.-Of the legumes, red clover for well-drained soils and alsike for wet lands are generally the most satisfactory. The clovers make their maximum growth during the months of April, May, and June. When the summer drought comes on, the quantity of forage produced gradually decreases. If a clorer pasture is utilized to its fullest capacity during the spring and early summer, it is necessary to provide additional green feed for the dry season. This may be done by grazing the clover meadow during the summer after removing a crop of hay.

Alfalfa.-Alfalfa is not used so generally as clover for hog pasture west of the Cascade Mountains. It has been tried in many localities with rarying degrees of success. It has given best satisfaction on the sandy or loamy soils along the watercourses where the water table is at least 4 feet below the surface. Alfalfa is highly successful in the Umpqua and Rogue River Valleys on irrigated and subirrigated land. Under conditions favorable to its growth, it produces an abundance of feed from early spring until late in the fall.

Rape in cultivated rows. - If grown in rows and kept well cultirated, rape furnishes excellent green forage during the dry season when clover pasture is cut short by the summer drought. In growing rape in rows the land is prepared early and kept in good condition until planting time. The best results are secured by making three plantings on approximately April 1, 15, and 30. These three areas are then pastured alternately, the hogs being changed from one to the other. By thorough cultivation rape can be kept growing all summer. It is usually large enough to pasture with light hogs in 6 to 8 weeks after planting. Before brood sows and other grown hogs are turned on the rape, it should be large enough so that they will feed upon the leares instead of biting off the stem or pulling up the plants. When the fall rains come, rape makes a vigorous growth and can be used until the ground is so wet that the soil is injured by the tramping of the hogs.

Rape and oats.-Summer pasture is also provided by sowing 1 bushel of oats and 4 pounds of rape seed per acre during the latter part of April or early in May. If sown too early in the spring the rains pack the soil so hard that the rape does poorly. Oats and rape pasture is used from the time the growth is 5 or 6 inches high until winter begins. When hogs are pastured on rape and oats they do not work on the latter very much (unless the pasture is grazed closely) until the oats are nearly ripe. In stripping the ripe grain from the straw considerable is dropped on the ground and corered by the tramping of the hogs. The grain that is corered in this way germinates when the fall rains begin. Both the oats and rape then grow vigorously and make excellent fall and winter pasture. 
Winter pasture is also provided by sowing rape with oats intended for hay or grain. When sown in this way the rape grows but little until after the oats are harvested and the autumn rains have begun.

Rape and clover.-One of the most satisfactory ways of providing summer pasture is to sow rape and clover together late in May or early in June. For the details of this method, see Farmers' Bulletin 271 of this department.

Rape in corn.-From 3 to 4 pounds of rape seed per acre are sometimes sown in corn during July, just before the last cultivation. If the corn is planted on a well-prepared seed bed and kept thoroughly cultivated, so that the soil will remain moist, the rape usually germinates in about five days. It then furnishes excellent green succulent forage during the autumn while the corn is being hogged off. If the

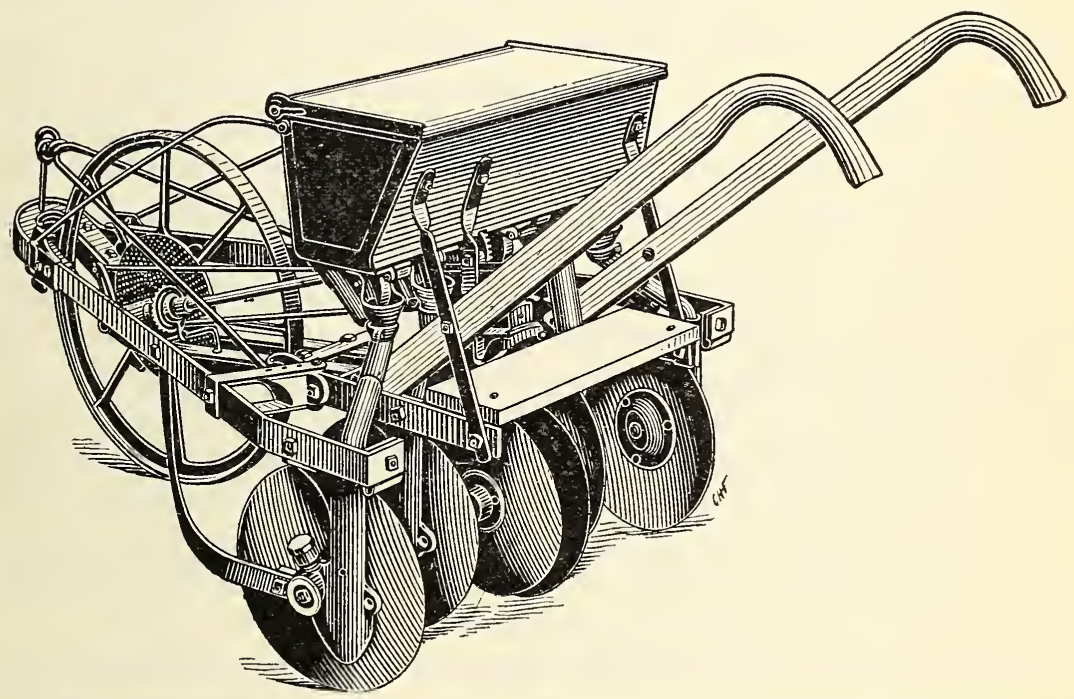

FIG. 5.-A one-horse disk grain drill used for planting grain between the rows of standing corn.

corn crop is husked or cut and removed from the field and the rape allowed to grow until late in the fall, the rape furnishes good pasture from November 1 to April 1.

Vetch and wheat, or vetch and oats, or vetch alone.-Vetch sown alone or with wheat or oats in corn at the last cultivation or in the early fall on spring-plowed stubble land furnishes pasture for hogs during the late fall, winter, and early spring. One bushel of vetch and a bushel of oats or 40 pounds of wheat are used per acre. If sown alone, from 90 to 120 pounds of vetch seed are required per acre. The seed is either planted with a one-horse grain drill which runs between the rows of corn or it is sown broadcast from the back of a horse. A one-horse disk grain drill, which can be used for this purpose, is shown in figure 5. If the latter method is used, a hood is placed over the head of the horse to keep the grain from falling into the animal's 
ears. If sown broadcast, the last cultivation of the corn covers the seed.

If vetch and wheat or oats are sown in corn when "laid by" in July, the pasture is ready for use by October 1; if sown on springplowed stubble land in the early fall, it is ready about Norember 1. The pasture may be used during the winter and early spring. If other pasture is not available, these crops will also furnish excellent forage for hogs until late in June. Vetch is also sown alone in the fall and used during.April, May, and June.

English rye-grass.-Owing to the excessive winter precipitation west of the Cascade Mountains, the ground is frequently so wet that the tramping of stock is very injurious to most soils. For this reason a grass pasture with a close, tough sod is very desirable for winter use. English rye-grass meets this need admirably. This grass forms a close sod that stands tramping well. It is one of the first grasses to begin growth in the spring and one of the last to cease growing in the fall. A rye-grass pasture may be used from the early autumn until the following July. During the summer drought, growth practically ceases. If kept grazed rather closely, the pasture will last for years.

A permanent English rye-grass pasture may be started by sowing from 10 to 15 pounds of seed per acre with oats or wheat in the early spring or fall. The grain crop is either thrashed or cut for hay. The grass is then ready for grazing the following autumn after being sown. A permanent pasture may be started also by sowing the grass seed with retch, oats, or wheat on stubble land in the early fall. The mixture of grass, retch, and grain is used for pasture the following winter and spring. The second year the pasture is a close grass sod that will stand grazing when the ground is wet.

Winter wheat.-Winter wheat sown in the early fall for a grain crop furnishes excellent pasture for hogs during February, March, and April.

GRAIN CROPS TO HOG OFF.

TABLE II.-Crops to hog off in western Oregon and western Washington.

\begin{tabular}{|c|c|c|}
\hline Crops. & When planted. & Approximate date when used. \\
\hline 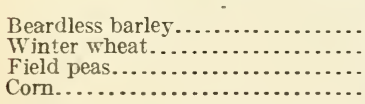 & 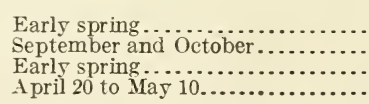 & $\begin{array}{l}\text { July } 1 \text { to July } 20 . \\
\text { July } 10 \text { to August } 10 . \\
\text { July } 25 \text { to October } 1 \text {. } \\
\text { September } 15 \text { to Norember } 15 \text {. }\end{array}$ \\
\hline
\end{tabular}

Wheat.-Hogs make rapid and economical gains on wheat until the chaff becomes thoroughly dry. If they are then supplied with green feed, they will do much better. If peas are not arailable for hogging off during August and September, wheat may be used until the autumn rains begin. Spring wheat may also be grown to take the place of the peas. 
Beardless barley.--If no winter wheat is available to hog off, its place may be filled with beardless barley. In fact this crop may take the place of corn and peas as well, being used from the time it is in the stiff-dough stage, about July 10, until winter rains come. Hogs do exceptionally well on it after the rains have softened the kernels.

Peas.-To furnish autumn pasture, one-half peck of wheat or a peck of oats is frequently sown with peas that are to be hogged off. In working upon the mature crop the hogs cause considerable of the oats or wheat to shatter out. Much of this is covered by the tramping of the hogs. When the first fall rains come it germinates and furnishes good pasture.

Corn.-Corn is hogged down to good advantage in much of the territory west of the Cascade Mountains for about six weeks - that is, from the time the kernels are pretty well glazed and dented until late in the fall. After the rainy season is well begun, the hogs get many of the ears down on the wet ground. This causes the corn to mold and spoil. For this reason it is not best to undertake to hog off too late in the season. In the Willamette Valley corn reaches the hogging-off stage about September 15. In the Rogue River Valley it is earlier and in northwestern Washington much latei than in the Willamette Valley.

SUCCULENT WINTER FEEDS.

TABLE III.-Succulent winter feeds for western Oregon and western Washington.

\begin{tabular}{|c|c|c|}
\hline Crops. & When planted. & When used. \\
\hline Kale.......... & $\begin{array}{l}\text { Planted in March or April; trans- } \\
\text { planted in June. }\end{array}$ & October 1 to April 1. \\
\hline 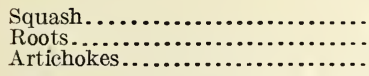 & 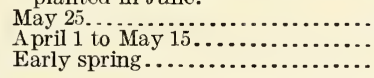 & $\begin{array}{l}\text { November } 1 \text { to January } 15 . \\
\text { November } 1 \text { to April } 1 . \\
\text { Do. }\end{array}$ \\
\hline
\end{tabular}

Thousand-headed kale.-Thousand-headed kale is an excellent succulent winter feed for hogs. The mild winters of western Oregon and western Washington permit kale to stand in the field all winter. It is cut and fed as needed. Unless fed in a rack or on a clean floor, pigs waste a great deal of the kale by tramping it in the mud. Full directions for growing kale will be found in Farmers' Bulletin 271 of this department.

Squashes.-In order to raise squashes successfully the land is manured heavily during the fall or winter, plowed about March 1, allowed to lie for five or six weeks, and then disked, harrowed, and clod mashed until in good condition. From May 1 to 15 it is replowed. Just before the seed is planted, about May 25, the soil is again cultivated.

The squashes are gathered about November 1, stored in a dark place in the barn, and covered with straw to keep them from freezing. They keep better if gathered before the surface of the squashes has been frozen. They are fed from approximately November 1 to January 15. 
Root crops.-The mangel-wurzels, half-sugar beet, sugar beet, and white French sugar beet are all used for hog feed. Beets may be stored either in pits or in bins in the barn, or fed from the field. Occasionally there is some loss from freezing if left in the field all winter. Usually, on the other hand, there is much to be gained by feeding from the field, because (1) beets make considerable growth during the late fall and winter, much of which is lost if they are stored; (2) when fed from the field the tops are utilized the same as the roots; and (3) it is much cheaper to feed from the field than to store them first and feed them later. Beets are fed whole.

Artichokes.-Artichokes are planted in rows and cultivated in precisely the same manner that potatoes are grown. The tubers are cut into rather small pieces and planted a little thicker and a little earlier than potatoes.

Artichokes are utilized by turning the hogs into the field in the fall after the tubers have made their growth. If the hogs have been ringed, the ground is loosened up with a plow, enough tubers being plowed out at a time to last a week.

The soil best adapted to the growth of artichokes for hogs is the sandy land along the watercourses. They can be hogged off on such land without seriously injuring the soil during the entire winter. The heavier soils are frequently badly puddled by the tramping of the hogs during wet weather. This can be counteracted by liberally applying coarse fresh manure or straw just before the hogs are turned into the field in the fall. By manuring heavily and working the ground early in the spring, artichokes may be grown on the same land for several years. They are sometimes allowed to rolunteer, the land being plowed, worked down, and the crop permitted to come from the tubers left in the soil. This is not good practice, however, it being much more profitable to plant them in rows, so that they can be cultivated. A crop of artichokes that is ready for the hogs is shown in figure 6.

Objection is sometimes made to artichokes on account of the difficulty of getting rid of them when it is desirable to grow some other crop on the land. They may be eradicated by sowing the land to clover, clover and rape, or clover and oats, and pasturing with sheep or cattle during the summer. If no stems and leaves are allowed to grow, no tubers will form. Close pasturing for one season will eliminate artichokes.

\section{CROPS FOR THE WHEAT BELT.}

The wheat belt of eastern Oregon, eastern Washington, and northern Idaho presents a great variety of agricultural conditions. The elevation above sea level varies from 1,000 to as much as 3,000 feet. The annual precipitation also varies from approximately 10 inches to 25 inches. In some of the more arid districts where the altitude 
is low, the soil is frequently so light that it is subject to blowing and drifting. In the districts where the precipitation is heaviest, on the other hand, the soil is a dark, fertile, silt loam. Owing to these variations crop production varies widely in the wheat belt. For convenience in discussing the cropping and feeding systems which may be used for hogs, the wheat belt is divided into (1) the subhumid or moister districts and (2) the arid and semiarid districts. There is no distinct line of demarcation between them, for they gradually blend into one another.

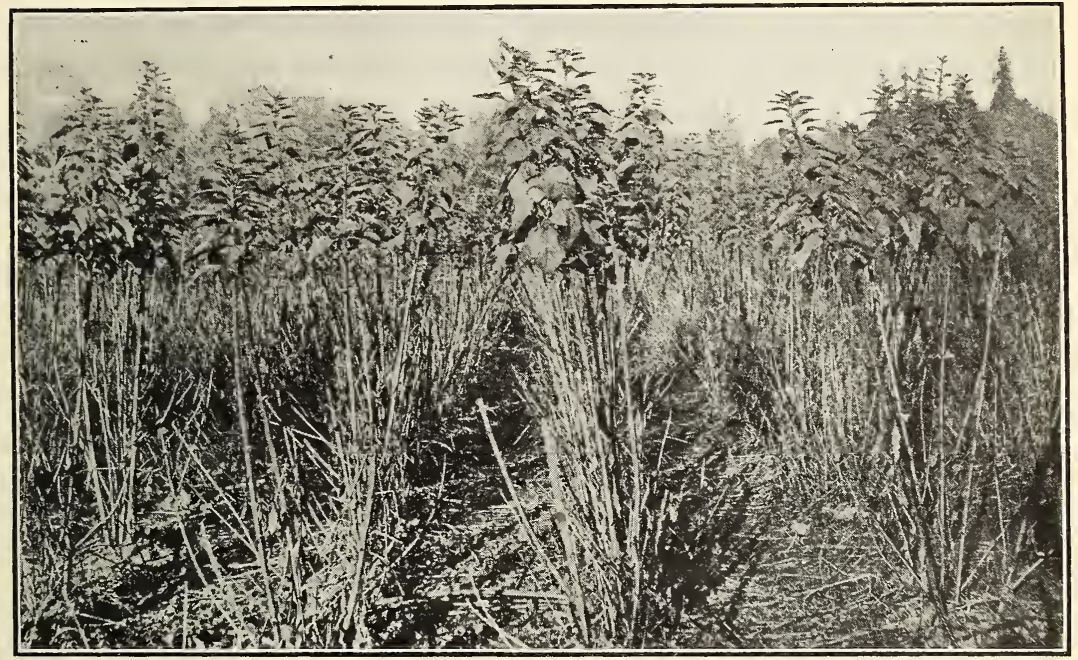

FIG. 6.-A field of artichokes in the Willamette Valley, Oreg., that is ready for the hogs. When the lower leaves began to die, sheep were turned in. They stripped off the leaves as high as they could reach. Cattle would consume the rest of the leaves.

Subhumid or Moister Pistricts.

The more humid portions of the wheat belt are generally situated near the mountains. The annual rainfall is usually sufficient to grow alfalfa successfully without irrigation.

USE OF VARIOUS PASTURE CROPS.

TABLE IV.-Pasture crops for the subhumid districts.

\begin{tabular}{|c|c|c|c|}
\hline Crops. & When planted. & Approximate dates when used. & $\begin{array}{l}\text { Number } \\
\text { of hogs an } \\
\text { acre will } \\
\text { pasture. }\end{array}$ \\
\hline Winter wheat. & Early in September. & October 15 to November 15 , & 5 to 8 \\
\hline Clover.. & April, previous year. & A pril 10 to December $1 . . . . .$. & 8 to 15 \\
\hline Alfalfa.... & A previous year..... & A pril 15 to November $15 . .$. & 8 to 15 \\
\hline Kale or rape....... & A pril and May.... & June 15 to December $1 . \ldots . .$. & 8 to 15 \\
\hline Rape and clover... & May $1 . . . . . . .$. & July 10 to November 15. & 6 to 14 \\
\hline Winter wheat........ & 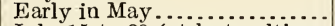 & June 1 to November $15 . . . . .$. & 6 to 15 \\
\hline Wheat in corn....... & $\begin{array}{l}\text { July } 15 \text { to } 20 \text { (at last cultiva- } \\
\text { tion of corn). }\end{array}$ & September 15 to November 15 . & 6 to 12 \\
\hline Stubble field. & - & August 25 to April $1 . .$. . & \\
\hline
\end{tabular}


Winter wheat.-Many farmers use the main winter-wheat field for hog pasture. If the autumn rains begin early enough in the fall to do the seeding during the first part of September, wheat usually makes sufficient growth to furnish pasture from October 15 until the ground is so wet that it is injured by the tramping of the hogs. If sown during September, winter wheat also makes very early spring pasture. It is used from the time the ground is settled until the grain begins to head, or until the hogs begin to chew the heads. Ordinarily this will be from March 15 until June 1.

Excellent summer and autumn pasture is provided by sowing winter wheat early in May on a well-prepared seed bed. If not pastured very closely during the autumn, wheat that is sown during May can be used during much of the winter.

If sown just before the last cultivation in corn that has been well cultivated, wheat generally furnishes an abundance of green feed during the autumn when corn is being hogged off.

Clover and alfalfa.--Red clover is adapted to the wheat-growing districts having a claylike subsoil and the maximum precipitation. While alfalfa is adapted to the same territory it has a much wider range of usefulness, for it succeeds with less rainfall and on lighter soils than clover. Clover begins to grow earlier in the spring and continues to grow later in the fall than alfalfa. The young tender growth of clover is not so easily injured by severe frosts as that of alfalfa. Red clover fits nicely into short rotations because it is short lived and so easily killed by plowing. Where the land is to be used continuously for hog pasture for a number of years alfalfa easily stands first.

The carrying capacity of both clover and alfalfa is greatly reduced by the summer drought, and it is usually necessary to provide additional feed during this time.

The essentials in successfully growing both of these crops are given in detail in Popular Bulletin 31 and Bulletin 80 of the Washington Agricultural Experiment Station, Pullman, Wask.

Kale and rape.-Thousand-headed kale and Dwarf Essex rape are very closely related. The mature individual kale plants are generally larger than those of rape. In the more humid portions of the wheat belt of Idaho, Oregon, and Washington few crops are more satisfactory for pasture during the summer and autumn than kale and rape. The green aphis sometimes attacks both of these crops during the last of August. While kale is seldom injured very much, rape is frequently damaged considerably. For this reason kale is the preferable crop. A field of kale is shown in figure 7 .

To grow either rape or kale successfully the land to be planted receives an application of stable manure and is plowed during the late fall. As soon as the surface soil is dry enough in the spring, 
it is thoroughly cultivated to destroy weeds, germinate weed seeds, and conserve moisture. For early summer use, say the middle of June, the seed is planted as early in the spring as the soil has warmed up well. If the crop is not to be used until July 15, the date of planting may be delayed until about May 1 . Seeding at that date gives an opportunity to cultivate the ground several times before the seed is planted. This makes it much easier to keep the crop free from weeds.

While kale and rape may be sown broadcast, the best results are secured by planting in rows about 32 inches apart. Kale is thinned until the plants stand 12 to 14 inches apart in the rows. Rape can be left a little thicker in the row.

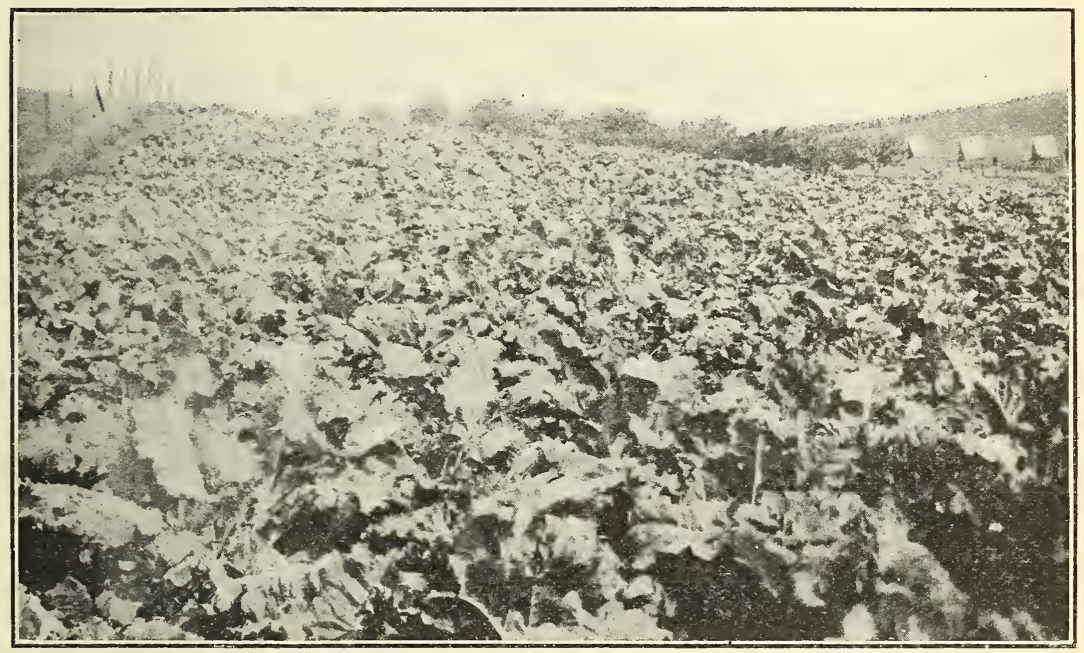

FIG. 7.-Thousand-headed kale on the college farm, Pullman, Wash., planted in drill rows 28 inches apart. (Photographed August 23, 1909.)

By pasturing and cultivating two or three times, the crop may be kept green all summer. After the fall rains come both rape and kale make a much better growth than clover or alfalfa. They stand a great deal of severe frost and can generally be used until about December 15. If used only during the late summer and autumn, better results are secured by cutting and feeding kale instead of turning the hogs into the field. When the plants are allowed to become large, the hogs break down and waste many of the leaves.

Rape and clover. - Summer pasture is provided and a stand of clover established at the same time by sowing 3 pounds of rape seed and 8 to 10 pounds of red-clover seed per acre about May 1. The seed is mixed and sown together according to the methods described for sowing clover in Popular Bulletin 31 of the Washington Agricultural Experiment Station. If sown May 1, the rape and clover should be 
large enough to pasture by July 1 to 10 . Rape makes excellent green forage while wheat, peas, and corn are being hogged off.

Gleaning stubble fields. - Wheat farmers who raise hogs give them the run of the stubble fields from the time the grain is harvested until the land is plowed the following spring. They feed upon the heads that are dropped in harvesting and also on the volunteer grain.

It is frequently supposed that the combined harvester and thrasher will leave so little grain in the field, especially on level ground, that there is nothing to be gained by gleaning the stubble with hogs. It is also supposed that in gleaning a large stubble field hogs will do so much traveling that they make no gains. To show that neither of these assumptions is well founded, the experience of W. H. Steen, Umatilla County, Oreg., in gleaning the stubble field with hogs may be cited.

On August 24, 1910, 90 head of hogs, weighing 6,261 pounds, were turned into 178 acres of wheat stubble. They were in the field without other feed until November 1, when they weighed 8,350 pounds. The gain in live weight per acre was 11.73 pounds. The ralue of the gain per acre $(11.73$ pounds) at 6,7 , and 8 cents per pound amounts to $70.4,82.1$, and 93.8 cents, respectively. The stubble land gleaned by the hogs is comparatively level, and a good job had been done in cutting the grain with a combined harrester. On steep land the waste in harvesting is always much greater than on level land, and the gain in gleaning the stubble with hogs should be correspondingly greater.

GRAIN CROPS TO HOG OFF.

TABLE V.-Crops to hog off in the subhumid district.

\begin{tabular}{|c|c|c|}
\hline Crops. & When planted. & Approximate dates when used.1 \\
\hline 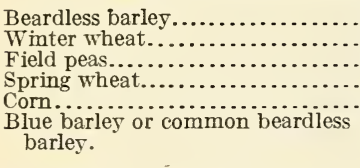 & 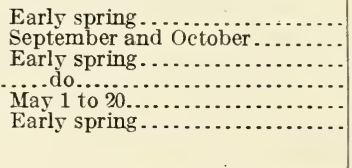 & $\begin{array}{l}\text { July } 5 \text { to August } 1 \text {. } \\
\text { July } 20 \text { to August } 20 . \\
\text { July } 10 \text { to November } 1 \text {. } \\
\text { August } 1 \text { to September } 1 \text {. } \\
\text { September } 1 \text { to November } 15 \text {. } \\
\text { From beginning of autumn rains } \\
\text { to midwinter. }\end{array}$ \\
\hline
\end{tabular}

1 Because of the great variation in altitude in the more humid portions of the wheat belt, there is a corresponding variation in the dates at which crops mature. Barley, wheat, and peas, for example, reach the hogging-off stage much earlier when grown at low altitudes than at high altitudes. For this reason the dates in the above table for using the crops are only approximately correct.

A discussion of the use of the crops mentioned in Table $\mathrm{V}$ will be found on pages 6 to 9 of this bulletin. The growing of wheat and barley is familiar to all and needs no further comment. The growing of field peas and corn are discussed in Popular Bulletins Nos. 36 and 38, and Bulletin 99 of the Washington Agricultural Experiment Station. These bulletins may be had by applying to the Director of the Agricultural Experiment Station, Pullman, Wash. 
WINTER FEEDS.

TABLE VI.-Winter feeds for the subhumid districts.

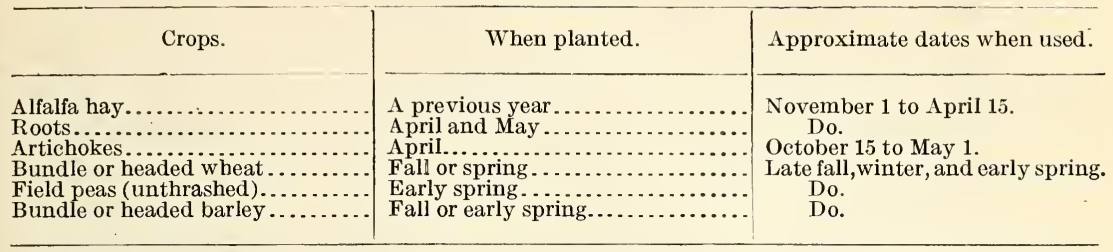

Alfalfa hay.-Alfalfa hay is probably the most satisfactory winter roughage that may be provided for hogs in the subhumid wheat districts. If intended for hogs, it is cut green a little before the appearance of the first blossoms. It is also best to take it from a portion of the field where the stand is thick. The hay will then be fine; pala table and rich in protein.

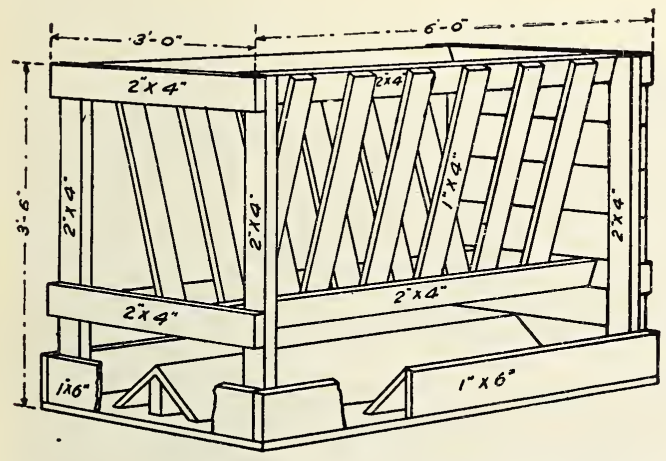

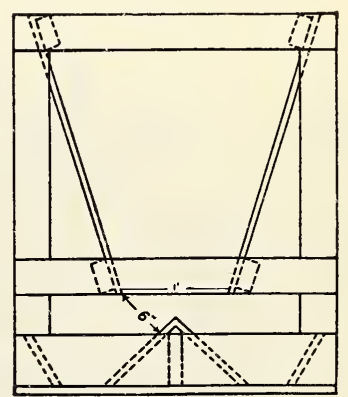

END VIEW OF RACK

FIG. 8.--Rack for feeding hay to hogs.

Alfalfa hay is usually fed in one of two ways, whole or cut. Whole hay is generally fed in racks. Figures 8 and 9 show racks used for feeding hay to hogs. Hay is also fed on the surface of the ground. By either of these methods there is considerable waste, especially if the hay is coarse. One of the most popular and satisfactory ways of feeding alfalfa hay to hogs is to run it through a hay cutter, chopping it into lengths of about one-half inch. The hay is then mixed with chopped or rolled wheat or barley. The mixture is moistened with all of the water that it will absorb, and allowed to stand for 12 hours before it is fed. Some soak the hay and add the grain just before feeding. During very cold weather the hay may be wet with hot water and fed immediately. Where it is not necessary to hasten the growth of the hogs alfalfa hay may form one-half of the ration by weight. Where a rapid gain is desired a ration consisting of onefourth alfalfa hay and three-fourths grain is more satisfactory.

Root crops.--The sugar beet, the white French sugar beet, mangels, carrots, and rutabagas are all used for fall and winter hog feed. 
The success of root crops largely depends upon the preparation of the seed bed. In growing sugar beets in the ricinity of Waverly, Wash., the following has been found a very satisfactory way of preparing land for this crop. Stubble land is disked or plowed shallow in the autumn. As soon as in condition to work in the early spring it is plowed 7 or 8 inches deep and then harrowed, planked, and rolled again and again until a firm, mellow seed bed is formed. The time of planting depends on the season. In localities whose altitude is from 2,000 to 2,500 feet, root crops are usually planted the last of April or early in May. For winter use roots are stored either in cellars or pits. Roots are generally fed in connection with a grain ration. The hogs usually receive all of the roots that they will clean up and sufficient grain to make them thrivive and grow as desired.

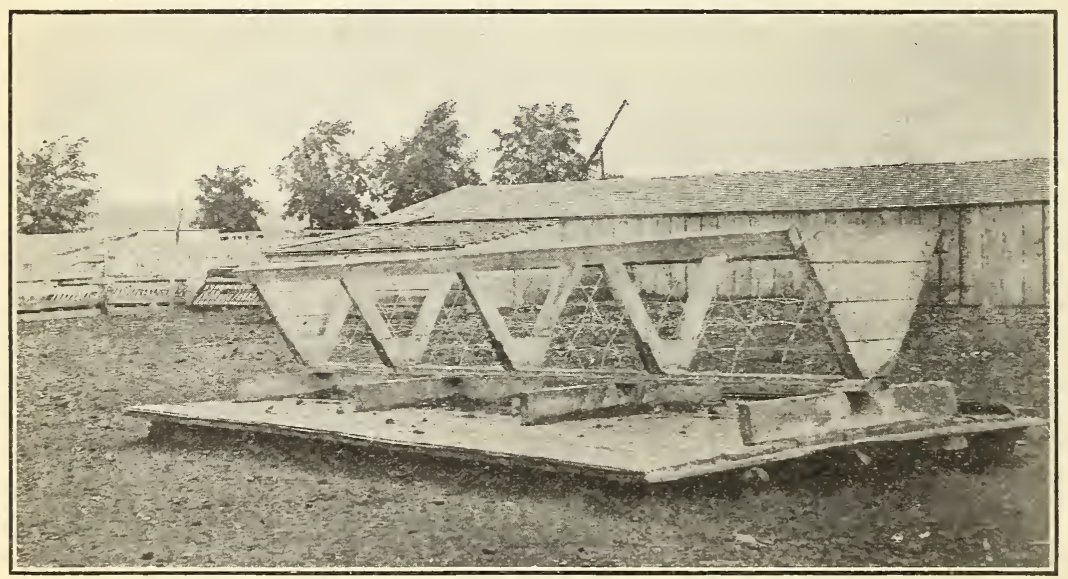

FIG. 9.-An easily and cheaply constructed rack for feeding hay to hogs. The sides consist of ordinary hog-fencing wire stapled on a frame.

Artichokes.-On rich, mellow land that retains moisture well artichokes usually yield better than potatoes. But on land that dries out quickly the yield is not very satisfactory. The methods given on page 16 of this bulletin for growing artichokes will apply in the main for this district also.

The hogs are turned in late in the fall, about the time that alfalfa or clover pasture is failing. Some allow the hogs to work on the tubers at will from the last of October until May 1. Others prefer to use artichokes only in the late fall and early spring, the hogs being removed from the field during the winter, when the ground is so wet that their rooting will puddle the soil. The hogs are returned to the field as soon as the ground has settled in the early spring. Used in this way artichokes fill in two periods, the late fall and early spring, when green feed is scarce. As with the root crops, hogs must also receive a grain ration of some kind when feeding upon artichokes if 
rapid gains are desired. When the ground is frozen hard other feed must be provided.

Unthrashed wheat.-Many hog raisers use headed or bundle wheat to carry dry brood sows and young shotes through the winter. When feeding upon the unthrashed grain the hogs get considerable roughage in chewing the heads. They are also compelled to eat more slowly and to masticate their food better than when feeding upon thrashed grain. When the grain is fed in the straw the thrashing bill is saved and the hogs are kept busy during much of the time. Unthrashed wheat and artichokes or roots of some kind make a good combination for wintering hogs.

Field peas.-In some localities field peas are stacked and the unthrashed vines fed to hogs during the late fall, winter, and early spring. Mature pea grain is a concentrated feed, very rich in protein. For this reason hogs should receive other feed in addition to the peas to dilute the ration. Any of the root crops, artichokes, or potatoes are excellent for this purpose.

Unthrashed barley.-In using unthrashed bearded barley for winter feed for hogs, a large quantity is thrown into the feed lot at a time in order that the beards and kernels may become wet and soften. If fed dry, the kernels are too hard to be eaten readily.

\section{Arid And Semiarid Districts.}

The arid and semiarid districts may arbitrarily be designated as that portion of the wheat belt whose normal precipitation is insufficient to grow alfalfa successfully. In much of this region, however, alfalfa can be grown profitably for hog pasture by keeping the stand very thin and cultivating it thoroughly in the late fall and early spring. If sown rather thinly in rows about 24 to 36 inches apart and cultivated occasionally during the spring and summer, alfalfa will make profitable hog pasture over a very wide territory now considered too dry for that crop. The crops mentioned in Table VII will provide pasture during much of the year in the dry region.

PASTURE CROPS.

TABLE VII.-Pasture crops for the arid and semiarid districts.

\begin{tabular}{|c|c|c|c|}
\hline Crops. & When planted.' & Approximate date when used. & $\begin{array}{l}\text { Number } \\
\text { of hogs } \\
\text { an acre } \\
\text { will } \\
\text { pasture. }\end{array}$ \\
\hline Winter wheat..... & October............ & April 1 to May $15 .$. & 6 to 10 \\
\hline Beardless barley... & February or March.. & May 1 to June $15 .$. & 5 to 10 \\
\hline Spring wheat................ & March.............. & May 1 to July $1 \ldots \ldots \ldots$ & 5 to 10 \\
\hline $\begin{array}{l}\text { Winter wheat or beardless } \\
\text { barley. }\end{array}$ & May................. & June 15 to August $1-25 .$. & 5 to 8 \\
\hline $\begin{array}{l}\text { Field corn and Early Amber } \\
\text { sorghum. } \\
\text { Stubble field.................. }\end{array}$ & April 10 to May $10 .$. & $\begin{array}{l}\text { July until autumn frosts... } \\
\text { August } 25 \text { to April } 15 . . . . .\end{array}$ & 4 to 7 \\
\hline
\end{tabular}


Wheat.-Wheat is used for hog pasture as follows:

(1) As soon as the surface of the ground is dry in the spring, about April 1, the hogs are turned into the main crop of winter wheat that is grown for market. Some prefer to use the winter wheat until it begins to joint; that is, for about a month or six weeks. Others use it until the hogs begin to chew the heads of wheat, and still others harvest with the hogs in the field.

(2) Spring wheat sown the last of February or early in March is generally large enough for pasture, 3 to 4 inches high, by May 1. By pasturing it rather closely it will stay green until about July 1.

(3) Summer pasture is provided by sowing either spring or winter wheat about May 1. Land that is sown at this date is plowed during the late fall, in the winter, or very early in the spring. To destroy weeds and retain moisture it is kept thoroughly cultivated from early spring until the wheat is sown. The pasture is ready for use in about six weeks from date of planting. If grazed closely, it should remain green until in August.

Barley.-The common beardless barley is also sown in the early spring and early in May for spring and summer pasture. Barley comes more quickly and makes more feed than wheat. The hogs also like it better than wheat up to the time it has headed out.

Corn and sorghum.-Field corn and sereral varieties of sorghum are grown in a limited way in the dry portion of the wheat belt for hog pasture. The principal rarieties of sorghum are kafir, Jertsalem corn, milo, and Amber sorghum. Just which of these is most satisfactory when grown as a grazing crop or to cut and feed green has not been fully determined. On account of the succulency and high sugar content of its stems as well as its habit of suckering after being cut or eaten down, Amber sorghum is probably the best of the rarieties named abore. The rariety grown is locally known as Early Amber sorghum. Field obserrations seem to indicate that Amber sorghum is best adapted to the extremely dry districts where the altitude is rather low, and corn to the higher districts. These crops need to be further tested in limited areas to determine which are most profitable.

Corn and sorghum are grown in much the same way. To be successful, the preparation of the seed bed must receire special attention. Perhaps the most satisfactory way to prepare the land for these crops is to plow during the late fall or winter and then cultirate thoroughly from early spring until planting time. Sorghum is planted a trifle later than corn, in rows 3 to $3 \frac{1}{2}$ feet apart with a grain drill. The seed is dropped 10 to 15 inches apart in the row. To firm the soil and cause the seed to germinate quickly, a corrugated roller or subsurface packer is run just behind the drill. The cultivation is the same as that of corn. The crop is either cut and fed green or the hogs are turned into the field when the sorghum or corn is 14 to 18 inches high. The former method gires by far the most feed.

Corn and sorghum are generally used in a 2-year rotation with wheat or barley, the land being in sorghum or corn for summer green feed one year and in barley or wheat to pasture or hog off the next. 
Gleaning stubble fields.-If the farm is fenced hog tight, the hogs have the run of the stubble field from the time the grain is harvested until the land is plowed the following spring. The volunteer grain makes the earliest green feed in the spring.

GRAIN CROPS TO HOG OFF.

TABLE VIII.-Crops to hog off in the arid and semiarid districts.

\begin{tabular}{|c|c|c|}
\hline Crops. & When planted. & Approximate dates when used.1 \\
\hline 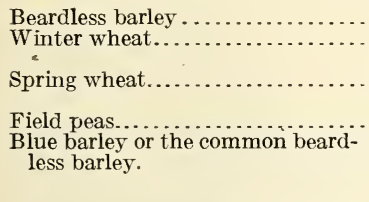 & 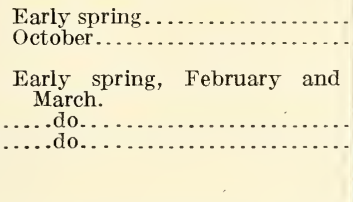 & $\begin{array}{l}\text { June } 20 \text { until autumn rains begin. } \\
\text { July } 1 \text { to opening of stubble field or } \\
\text { until autumn rains begin. } \\
\text { July } 15 \text { to opening of stubble field or } \\
\text { until autumn rains begin. } \\
\text { July } 20 \text { until autumn rains begin. } \\
\text { From beginning of autumn rains to } \\
\text { late winter-October } 15 \text { to Feb- } \\
\text { ruary } 10 \text {. }\end{array}$ \\
\hline
\end{tabular}

1 The altitude of the arid and semiarid districts varies from 1,000 to 3,000 feet. For this reason the dates at which the crops in the above table mature will vary considerably. The dates given for the use of these crops, therefore, are only approximations.

Whether or not wheat and peas shall be used from the time they are available in the early summer until the autumn rains have softened the barley sufficiently to be hogged down will depend upon the number of hogs kept on the farm. Where only enough hogs are kept to glean the stubble field, peas and wheat are used only until the grain is thrashed and the stubble field is open. Where more than enough hogs are kept to clean up the stubble field, wheat and peas can be profitably hogged off until the barley is in condition to use.

Somewhat limited observations indicate that field peas in the dry parts of the wheat belt seldom have nodules on their roots. The yield also is usually light. The lack of nodules, the light yields, and the high price of seed make the production of peas questionable. It is probable that they may be grown profitably in rows as a cultivated crop. At the experimental farm at Moro, Oreg., peas are planted in double rows 7 inches apart with 35 -inch spaces between the double rows. The peas are planted in this way with a grain drill by stopping up a part of the feed cups. The peas support each other and stand up better when planted in this way. They are cultivated with a spike-tooth harrow until about 4 or 5 inches high. They then receive shallow cultivation between the rows until the vines lop over.

WINTER FEEDS.

The feeds that may be used economically to carry hogs through the winter are standing barley and headed wheat. Field peas may also be stacked and fed without thrashing.

\section{CROPS FOR THE IRRIGATED VALLEYS.}

Much of the irrigated land along the Columbia River, on the one extreme, is less than 400 feet above the level of the sea. Some of the irrigated mountain valleys, on the other hand, have an elevation of 
3,500 to 4,000 feet. At the low altitudes pasture is arailable much earlier in the spring and later in the autumn than at the higher altitudes. In the mountain valleys all of the grain fed is raised, while in the lower districts most of the grain consumed is purchased from the near-by wheat farms. In the lower districts corn is successfully grown. In the higher valleys corn has not proved a success.

PASTURE CROPS.

TABLE IX.-Pasture crops in the irrigated valleys.

\begin{tabular}{|c|c|c|c|}
\hline Crops. & When planted. & Approximate dates when used. & $\begin{array}{l}\text { Number } \\
\text { of hogs an } \\
\text { acre will } \\
\text { carry. }\end{array}$ \\
\hline 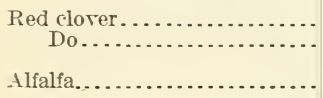 & $\begin{array}{l}\text { Previous year.............. } \\
\text { Early spring with wheat, oats, } \\
\text { or barley. } \\
\text { Previous year ................. }\end{array}$ & $\begin{array}{l}\text { March } 25 \text { to Norember } 10 . . . . \\
\text { After grain is harvested to } \\
\text { Norember } 10 \text {. } \\
\text { April } 1 \text { to to Norember } 1 . . . . .\end{array}$ & $\begin{array}{l}10 \text { to } 20 \\
10 \text { to } 20 \\
10 \text { to } 20\end{array}$ \\
\hline
\end{tabular}

Alfalfa is most generally used for hog pasture under irrigation. There are many who prefer clover, however, especially in the mountain valleys, because it starts growth earlier in spring and is less injured by fall frost than alfalfa. The two crops are sometimes grown together. It is claimed that a mixture of the two will carry nearly one-third more hogs per acre than either grown alone.

In the mountain valleys where the cereals are important crops, clorer fits into the rotations better than alfalfa. In the Powder River Valley, Oreg., red clorer is grown in a 2-year rotation with wheat, oats, or barles. The clover is sown in the early spring and after the grain is harrested makes excellent pasture until winter. The following June a crop of hay is cut. About the middle of July, when the second crop is about 10 inches high, the clover is plowed under and the ground worked down immediately. The following spring the land is again sown to clover and wheat, oats, or barley. Where there is plenty of water for irrigation throughout the season, the clorer sod is not plowed under until during the autumn.

WINTER FEEDS.

TABLE X.-Winter feeds in the irrigated valleys.

\begin{tabular}{|c|c|c|}
\hline Crops. & When planted. & When used. \\
\hline 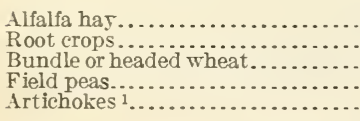 & 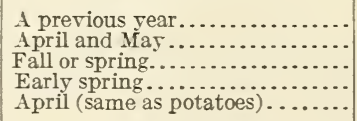 & $\begin{array}{l}\text { Norember } 1 \text { to April } 15 . \\
\text { Do. } \\
\text { Late fall, winter, and early spring. } \\
\text { Do. } \\
\text { Norember } 1 \text { to April } 15 .\end{array}$ \\
\hline
\end{tabular}

1 Artichokes are best adapted to the lower irrigated districts, where the winters are open enough to permit the hogs to work on the tubers. They are used from the time that alfalfa pasture fails in the autumn until it is available again in the spring. Even in the lower valleys there are times during the winter when the ground is frozen too hard for the hogs to root out the tubers. Alfalfa hay, roots, or other feed must then take the place of the artichokes.

A discussion of the use of these crops will be found under "Winter feeds," pages 21 to 23 . 
CROPS TO HOG OFF.

TABLE XI.-Crops to hog off in the irrigated valleys.

\begin{tabular}{|c|c|c|}
\hline Crops. & When planted. & Approximate dates when used. 1 \\
\hline $\begin{array}{l}\text { Beardless barley...... } \\
\text { Club wheat.......... } \\
\text { Field peas........... } \\
\text { Club wheat.......... }\end{array}$ & 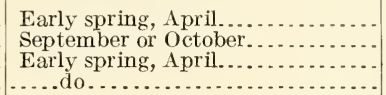 & $\begin{array}{l}\text { August } 1 \text { to November } 15 \text {. } \\
\text { August } 5 \text { to September } 15 \text {. } \\
\text { August } 20 \text { to November } 15 \text {. } \\
\text { August } 20 \text { to October } 1 .\end{array}$ \\
\hline
\end{tabular}

1 The dates for using the crops in the table above are applicable to localities whose altitudes range from 3,000 to 4,500 feet. At lower altitudes these crops are ready for use much earlier.

The hogging off of crops under irrigated and nonirrigated conditions is so similar that the discussion of the use of these crops on pages 5 to 10 and 14 and 15 of this bulletin will be found applicable in the irrigated districts.

\section{SUMMARY.}

During recent years the hog industry in the Pacific Northwest has been inadequate to supply the local demands for pork and pork products. This has caused the average price of pork to be relatively high and has made it necessary to ship a large percentage of the hogs slaughtered and bacon consumed from east of the Rocky Mountains.

It is possible to provide pasture for hogs in most of this region throughout much of the year. In most localities it is also possible to provide crops that may be hogged off during several months of the busy season. The crops generally used for this purpose are wheat, field peas, corn, and barley. By supplementing well-managed pasture with the proper grain rations and utilizing the ability of the hog to harvest grain crops for himself, the average cost of producing pork may be materially reduced. These conditions offer an opportunity for profitable pork production in the Pacific Northwest on a much larger scale than at present practiced. 


